\title{
Contributions of Dopamine DI, D2, and D3 Receptor Subtypes to the Disruptive Effects of Cocaine on Prepulse Inhibition in Mice
}

\author{
James M Doherty', Virginia L Masten', Susan B Powell', Rebecca J Ralph', Daniel Klamer², Malcolm J Low ${ }^{3}$ \\ and Mark A Geyer*, I \\ 'Department of Psychiatry, University of California, San Diego, La Jolla, CA, USA; '2Department of Pharmacology, Göteborg University, Göteborg, \\ Sweden; ${ }^{3}$ Center for the Study of Weight Regulation, Department of Behavioral Neuroscience and Vollum Institute, Oregon Health and Science \\ University, Portland, OR, USA
}

Deficits in prepulse inhibition (PPI) of startle, an operational measure of sensorimotor gating, are characteristics of schizophrenia and related neuropsychiatric disorders. Previous studies in mice demonstrate a contribution of dopamine (DA) $D_{1}$-family receptors in modulating PPI and DA $D_{2}$ receptors (D2R) in mediating the PPI-disruptive effects of amphetamine. To examine further the contributions of DA receptor subtypes in PPI, we used a combined pharmacological and genetic approach. In congenic C57BL/6 J wildtype mice, we tested whether the DIR antagonist $\mathrm{SCH} 23390$ or the D2/3R antagonist raclopride would attenuate the effects of the indirect DA agonist cocaine $(40 \mathrm{mg} / \mathrm{kg})$. Both the DIR and D2/3R antagonists attenuated the cocaine-induced PPI deficit. We also tested the effect of cocaine on PPI in wild-type and DA DIR, D2R, or D3R knockout mice. The cocaine-induced PPI deficit was influenced differently by the three DA receptor subtypes, being absent in DIR knockout mice, partially attenuated in D2R knockout mice, and exaggerated in D3R knockout mice. Thus, the DIR is necessary for the PPI-disruptive effects of cocaine, while the D2R partially contributes to these effects. Conversely, the D3R appears to inhibit the PPI-disruptive effects of cocaine. Uncovering neural mechanisms involved in PPI will further our understanding of substrates of sensorimotor gating and could lead to better therapeutics to treat complex cognitive disorders such as schizophrenia.

Neuropsychopharmacology (2008) 33, 2648-2656; doi:I0.1038/sj.npp. I 30 I657; published online 12 December 2007

Keywords: prepulse inhibition; cocaine; mice; dopamine receptors; $\mathrm{SCH} 23390$; raclopride

\section{INTRODUCTION}

Prepulse inhibition (PPI) is a cross-species measure of sensorimotor gating in which startle magnitude is reduced when the startling stimulus is preceded by a low-intensity prepulse (Hoffman and Ison, 1980). PPI deficits are observed in psychotic disorders, such as schizophrenia, and are associated with dopamine (DA) dysregulation (Braff et al, 2001; Swerdlow et al, 2001). PPI deficits are modeled in mice and rats following treatment with psychotomimetic drugs, such as $d$-amphetamine, cocaine, or phencyclidine (Geyer et al, 2001).

Similar to the rat, the DA $D_{2}$ receptor (D2R) subtype is necessary for amphetamine-induced PPI disruptions in mice, while the DA $\mathrm{D}_{1}(\mathrm{D} 1 \mathrm{R}), \mathrm{D}_{3}(\mathrm{D} 3 \mathrm{R})$, and $\mathrm{D}_{4}(\mathrm{D} 4 \mathrm{R})$

*Correspondence: Professor M Geyer, Department of Psychiatry, University of California, San Diego, 9500 Gilman Drive, La Jolla, CA 92093-0804, USA, Tel: + I 619543 3582, Fax: + I 6195432493 , E-mail: mgeyer@ucsd.edu

Received 21 August 2007; revised 12 November 2007; accepted 13 November 2007 receptor subtypes are not (Ralph et al, 1999; RalphWilliams et al, 2002). DA $\mathrm{D}_{2}$-like agonists quinpirole and quinelorane failed to disrupt PPI in several strains of mice (Ralph-Williams et al, 2003; Ralph and Caine, 2005), although quinelorane can disrupt PPI in some mouse strains (Ralph and Caine, 2007). Relative to the rat, the D1R plays a more prominent role regulating PPI in mice (Geyer et al, 2002; Ralph-Williams et al, 2003; Ralph and Caine, 2005). The D1R antagonist SCH 23390 blocks the PPIdisruptive effect of the direct DA agonist apomorphine in mice, and $D_{1}$-family agonists such as SKF82958, SKF81297, and dihydrexidine reduce PPI in mice, supporting the idea that D1R activation is sufficient to produce PPI disruptions in mice (Holmes et al, 2001; Ralph-Williams et al, 2002, 2003). Thus, the roles of DA receptor subtypes in the modulation of PPI in mice appear to differ from those observed in rats.

Cocaine is an indirect DA agonist, which inhibits the reuptake of DA in the synapse, producing behavioral stimulation and precipitating psychosis after sustained use in humans (Bolla et al, 1998). Acute cocaine administration disrupts PPI in rats (Martinez et al, 1999; Byrnes and 
Hammer, 2000) and mice (our unpublished data; Yamashita et al, 2006) at high doses. Other studies, however, have failed to show an acute effect of cocaine on PPI in rats (Varty and Higgins, 1998). The behavioral effects of cocaine appear to be mediated by both $\mathrm{D}_{1}$ - and $\mathrm{D}_{2}$-family receptors. D2Rs regulate the increase in extracellular DA concentrations elicited by cocaine (Rouge-Pont et al, 2002). The D2/ $3 \mathrm{R}$ antagonist raclopride blocked the locomotor-stimulating effects of cocaine in mice (Chausmer et al, 2002). Xu and colleagues (Xu et al, 1994, 2000; Xu, 1998) found that D1R knockout (KO) mice exhibit an attenuated locomotor response after acute or repeated cocaine and proposed that D3Rs modulate responses to psychostimulants by inhibiting the cooperative effects of postsynaptic $\mathrm{D}_{1}$ - and $\mathrm{D}_{2}$-family receptors. Carta et al (2000) reported that D3R KO mice show enhanced locomotor activity following cocaine administration. The D1R activates and the D3R inhibits gene expression of extracellular kinases and c-fos induction after acute and chronic cocaine treatment (Zhang et al, 2004). Taken together, these reports suggest that all three DA receptor subtypes regulate the behavioral effects of cocaine and that they may exert different influences on behavior. To examine contributions of the DA D1R, D2R, and D3R subtypes to cocaine-induced deficits in acoustic startle response (ASR) and PPI, we pretreated WT mice with the D1R antagonist SCH23390 or the D2/3R antagonist raclopride, in addition to testing $\mathrm{D} 1 \mathrm{R}, \mathrm{D} 2 \mathrm{R}$, and $\mathrm{D} 3 \mathrm{R}$ KO mice.

\section{MATERIALS AND METHODS}

\section{Animals}

Incipient congenic D1R, D2R, and D3R mutant mice were bred and genotyped at Oregon Health \& Science University (OHSU) and shipped to the University of California, San Diego (UCSD) for testing. Before testing, mice had a minimum 2-week resting period to acclimate to our facilities to minimize any influences of travel. The wildtype (WT) mice used for the pharmacological experiment were taken from a cohort of D2R mice. WT mice from D1R, D2R, or D3R cohorts display no difference in PPI or ASR (Ralph et al, 1999).

A colony of D1R mutant mice (Drago et al, 1994) was originally established at OHSU from breeding stock of B6.129S4-Drd1 $\mathrm{a}^{\mathrm{tm} 1 \mathrm{Jcd}}$ male mice obtained from The Jackson Laboratory (Bar Harbor, ME). The heterozygous (HET) mice had been backcrossed for a minimum of five generations onto the inbred C57BL/6J line before importation and were then backcrossed for two additional generations in Portland (OHSU, Vollum Institute) to produce incipient congenic (N7) mice. N7 C57BL/6J D1R HET breeding pairs were used to generate the mice for behavioral studies. Because the D1R KO mice were growthretarded (Drago et al, 1994), pups were not weaned from their mothers until 4 weeks of age and were then provided with moistened chow until approximately 8 weeks of age to maximize growth. The D1R mice were genotyped by PCR using a protocol and primer sequences provided by The Jackson Laboratory.

The D2R mutant mice (Kelly et al, 1997, 1998), official strain designation $\mathrm{B} 6.129 \mathrm{~S} 2-\mathrm{Drd} 2^{\text {tm1Low }}$, were originally generated at OHSU and backcrossed for 14 generations (N14) onto the inbred C57BL/6J line. N14 C57BL/6J D2R HET breeding pairs were used to generate fully congenic mice used in behavioral studies. Both sexes of D2R KO mice were smaller than their WT siblings at the time of weaning, but they did not require special attention or moistened chow. The D2R KO mice later achieved weight close to that of the WT mice. D2R mice were genotyped by PCR according to the protocol previously described (Díaz-Torga et al, 2002).

D3R mutant mice (Accili et al, 1996), original strain B6.129S4-Drd3 ${ }^{\mathrm{tm} 1 \mathrm{Dac}}$, were also imported from The Jackson Laboratory. The mice were incipient congenic (N5 C57BL/6J D3R), having been backcrossed five times with the inbred strain C57BL/6J at the time of importation. The colony was established at OHSU and backcrossed for two more generations with the C57BL/6J to generate N7 D3R mice. N7 C57BL/6J D3R HET breeding pairs were used to generate mice for behavioral studies. All the mice were viable and fertile and no altered growth phenotype was present in these mutant mice. D3R mice were genotyped by PCR using a protocol and primer sequences provided by the Jackson Laboratory.

\section{Testing}

At UCSD, mice were housed in a climate-controlled animal colony with a reversed day/night cycle (lights on at 2000 hours, off at 0800 hours). All behavioral testing was performed on mice between 7 and 33 weeks of age and occurred between 0900 hours and 1700 hours daily. Food (Harlan Teklab, Madison, WI) and water were available ad libitum, except during behavioral testing. All behavioral testing procedures were approved by the UCSD institutional animal care and use committee prior to the onset of the experiments. Mice were maintained in American Association for Accreditation of Laboratory Animal Care approved animal facilities at UCSD. This facility meets all Federal and State requirements for animal care.

\section{Drugs}

$\mathrm{SCH} 23390 \mathrm{HCl}$ was dissolved in sterile water at a concentration of $0.2 \mathrm{mg} / \mathrm{ml}$ and a dose of $1.0 \mathrm{mg} / \mathrm{kg}$ was given subcutaneously $10 \mathrm{~min}$ before cocaine administration. Raclopride tartrate was dissolved in $0.9 \%$ saline at a concentration of $0.6 \mathrm{mg} / \mathrm{ml}$ and a dose of $3.0 \mathrm{mg} / \mathrm{kg}$ was given intraperitoneally $10 \mathrm{~min}$ before cocaine administration. Cocaine $\mathrm{HCl}$ was dissolved in $0.9 \%$ saline at a concentration of $8 \mathrm{mg} / \mathrm{ml}$ and a dose of $40.0 \mathrm{mg} / \mathrm{kg}$ was given intraperitoneally $5 \mathrm{~min}$ before behavioral testing. All three drugs were obtained from Sigma/RBI (St Louis, MO) and injected at a volume of $5 \mathrm{ml} / \mathrm{kg}$ body weight. The doses of SCH23390, raclopride, and cocaine were chosen based on pilot studies in C57BL/6J mice from our lab, as well as Yamashita et al (2006), for cocaine.

\section{Apparatus}

Startle reactivity was measured using eight startle chambers (SR-LAB, San Diego Instruments, San Diego, CA). Each chamber consisted of a clear nonrestrictive Plexiglas 
cylinder (inner diameter $=38 \mathrm{~cm}$ ) resting on a platform inside a ventilated box. A high-frequency loudspeaker inside the chamber produced both a continuous background noise of $65 \mathrm{~dB}$ and the various acoustic stimuli. Vibrations of the Plexiglas cylinder caused by the wholebody startle response of the animal were transduced into analog signals by a piezoelectric unit attached to the platform. These signals were then digitized and stored by a computer. Sixty-five readings were taken at $1 \mathrm{~ms}$ intervals, starting at stimulus onset, and the average amplitude was used to determine the ASR. The SR-LAB calibration unit was used routinely to ensure consistent stabilimeter sensitivity between test chambers and over time, and sound levels in $\mathrm{dB}$ SPL (A scale) were measured as described previously (Geyer and Dulawa, 2003).

\section{PPI Session}

All PPI test sessions consisted of startle trials (PULSEALONE), prepulse trials (PREPULSE + PULSE), and nostimulus trials (NOSTIM). The PULSE-ALONE trial consisted of a 40-ms 120-dB pulse of broad-band noise. PREPULSE + PULSE trials consisted of a 20-ms noise prepulse, $80 \mathrm{~ms}$ delay, then a $40-\mathrm{ms} 120-\mathrm{dB}$ startle pulse (100 ms onset to onset). The acoustic prepulse intensities were 69,73 , and $81 \mathrm{~dB}$ (ie 4,8 , and $16 \mathrm{~dB}$ above the $65-\mathrm{dB}$ background noise). The NOSTIM trial consisted of background noise only. The test session began and ended with five presentations of the PULSE-ALONE trial; in between, each acoustic or NOSTIM trial type was presented 10 times in a pseudo-random order. There was an average of $15 \mathrm{~s}$ (range: 12-30 s) between trials. A background noise level of $65 \mathrm{~dB}$ was presented for a 10 -min acclimation period and continued throughout the test session.

\section{Data Analyses}

For receptor comparison purposes, ASR and PPI were analyzed during the initial half of the session, where a significant cocaine effect occurred in all WT mice. Unless otherwise indicated, data were collapsed across sex when there were no interactions of cocaine treatment with sex. The amount of PPI was calculated as a percentage score for each acoustic prepulse trial type: $\%$ PPI $=100-\{[$ (startle response for PREPULSE + PULSE)/(startle response for PULSE-ALONE) $] \times 100\}$. For brevity, data are presented as the average \% PPI across the three prepulse intensities tested because of a lack of a treatment $\times$ intensity effect during analysis. The magnitude of the ASR was calculated as the average response of the PULSE-ALONE trials, excluding the first block of five PULSE-ALONE trials presented. Data from the NOSTIM trials are not included in the Results section because the values were negligible relative to values on trials containing startle stimuli.

\section{Pharmacological Blockade of Cocaine Effects on PPI}

The WT cohort consisted of 16 male and 15 female mice. The mice were first characterized in a session to establish their baseline startle magnitude and PPI levels. They were then assigned to their drug treatment groups $(40.0 \mathrm{mg} / \mathrm{kg}$ cocaine or vehicle), balanced for baseline startle magnitude,
PPI, and startle chamber assignment. The mice were tested in a three-way crossover design with 1 week between tests. Each animal always received either vehicle or cocaine as their treatment over the three tests. For the pretreatment, each animal received vehicle, $1.0 \mathrm{mg} / \mathrm{kg} \mathrm{SCH} 23390$, or $3.0 \mathrm{mg} / \mathrm{kg}$ raclopride in a semi-randomized, counterbalanced order, to complete a within-subject design. Thus, treatment was the between-subject variable and pretreatment was a within-subject variable. A two-way analysis of variance (ANOVA) was used to compare means, and the $\alpha$-level was adjusted to $P<0.025$ to accommodate the removal of treatment as a factor in the post hoc ANOVAs. The computations were carried out using the BMDP statistical software (Statistical Solutions Inc., Saugus, MA).

\section{Effects of Cocaine in D1R, D2R, and D3R WT and KO Mice}

The D1R cohort consisted of $15 \mathrm{WT}$ and $7 \mathrm{KO}$ male mice, and $10 \mathrm{WT}$ and $7 \mathrm{KO}$ female mice. The D2R cohort consisted of $28 \mathrm{WT}$ and $18 \mathrm{KO}$ male mice, and $16 \mathrm{WT}$ and $30 \mathrm{KO}$ female mice. The D3R cohort consisted of $9 \mathrm{WT}$ and $9 \mathrm{KO}$ male mice, and $10 \mathrm{WT}$ and $10 \mathrm{KO}$ female mice. The cohorts were characterized initially in a session to establish their baseline startle magnitude and PPI levels. They were then assigned to their drug treatment groups $(40.0 \mathrm{mg} / \mathrm{kg}$ cocaine or vehicle), balanced for baseline startle magnitude, PPI, and startle chamber assignment. The cohorts were tested in a semi-randomized, crossover design. After the first treatment, the mice were tested 1-2 weeks later to counterbalance for treatment, to complete a within-subject design. In the statistical analyses, genotype was the between-subject variable and drug was a withinsubject variable. A two-way ANOVA was used to compare means and the $\alpha$-level was adjusted to $P<0.025$ to accommodate the removal of genotype as a factor in the post hoc ANOVAs.

\section{RESULTS}

\section{D1 or D2/3 Antagonist Interactions with Cocaine}

Cocaine $(40 \mathrm{mg} / \mathrm{kg})$ produced PPI deficits in WT mice compared to vehicle pretreated controls $\left(\mathrm{F}_{(1,29)}=10.0\right.$; $P<0.01)$ (Figure 1). Pretreatment with $\mathrm{SCH} 23390(1.0 \mathrm{mg} /$ $\mathrm{kg}$ ), a D1R antagonist, attenuated the PPI deficit produced by cocaine as evidenced by a main effect of pretreatment $\left(\mathrm{F}_{(1,29)}=22.6 ; \quad P<0.01\right)$ and a pretreatment $\times$ treatment interaction $\left(\mathrm{F}_{(1,29)}=12.7 ; P<0.01\right)$ (Figure 1). Pretreatment with raclopride $(3.0 \mathrm{mg} / \mathrm{kg})$, a D2/3R antagonist, also attenuated the PPI deficit produced by cocaine as evidenced by a main effect of pretreatment $\left(\mathrm{F}_{(1,29)}=15.2 ; P<0.01\right)$ and a pretreatment $\times$ treatment interaction $\left(\mathrm{F}_{(1,29)}=8.2\right.$; $P<0.01$ ) (Figure 1). There were no effects of cocaine on ASR in WT animals, regardless of pretreatment with vehicle, SCH23390, or raclopride (Table 1). There was a main effect of sex on ASR with male mice exhibiting higher startle than female counterparts in all experiments, regardless of genotype $(P<0.05)$. 


\section{$D_{1}$ Receptor Mice}

There was a significant effect of cocaine $\left(\mathrm{F}_{(1,37)}=11.6\right.$; $P<0.01)$ and a genotype $\times$ cocaine interaction $\left(\mathrm{F}_{(1,37)}=4.6\right.$; $P<0.05)$ on PPI in D1R mice. Post hoc ANOVAs revealed that cocaine $(40 \mathrm{mg} / \mathrm{kg})$ significantly reduced PPI in D1R WT mice $\left(\mathrm{F}_{(1,24)}=15.1 ; P<0.01\right)$, but was ineffective in D1R KO mice (Figure 2a). Regardless of sex or drug treatment, D1R KO mice showed higher startle responses compared to WT control mice $\left(\mathrm{F}_{(1,37)}=7.6 ; P<0.01\right)$ (Table 1).

\section{$\mathrm{D}_{2}$ Receptor Mice}

Cocaine $(40 \mathrm{mg} / \mathrm{kg})$ produced PPI deficits in both D2R WT and $\mathrm{KO}$ mice (main effect of cocaine, $\mathrm{F}_{(1,90)}=73.9 ; P<0.01$ ) (Figure 2b). Nevertheless, there was a genotype $\times$ cocaine interaction $\left(\mathrm{F}_{(1,90)}=5.2 ; P<0.05\right)$, indicating that there was a significant difference in the magnitude of the PPIdisruptive effects of cocaine between the two genotypes. Specifically, the PPI-disruptive effects of cocaine were attenuated in D2R KO mice compared to WT mice. Cocaine significantly reduced ASR in male D2 WT mice only $\left(\right.$ drug $\times$ sex $\times$ gene interaction $\left.\mathrm{F}_{(1,88)}=4.8 ; P<0.05\right)$. Fe-

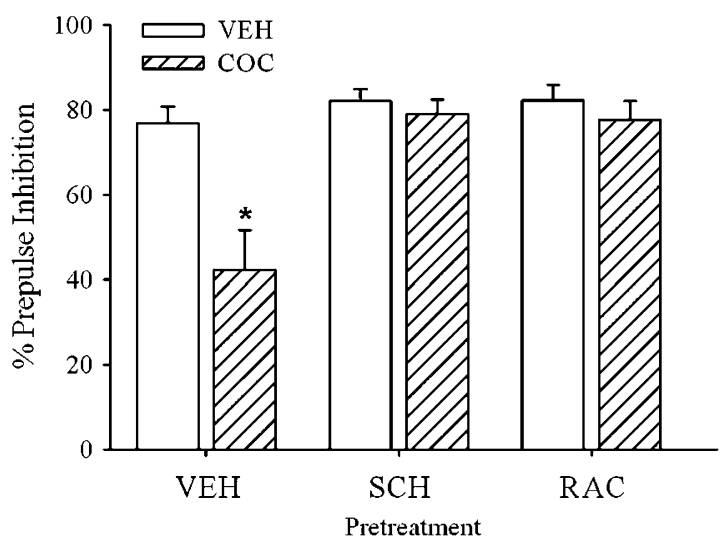

Figure I Prepulse inhibition of the startle response in WT mice after pretreatment with vehicle (VEH), I.0 mg/kg SCH23390 (SCH) or $3.0 \mathrm{mg} / \mathrm{kg}$ raclopride (RAC) and treatment with vehicle or $40.0 \mathrm{mg} / \mathrm{kg}$ cocaine (COC). Cocaine decreased PPI in WT mice and both $\mathrm{SCH} 23390$ and raclopride attenuated the cocaine-induced PPI deficit. $* P<0.01$ compared to vehicle control. Data are presented as mean \pm SEM. male D2R KO mice exhibited reduced startle compared to WT littermates, regardless of drug treatment (sex $\times$ gene interaction $\left.\mathrm{F}_{(1,88)}=4.4 ; P<0.05\right)$ (Table 1).

\section{$\mathrm{D}_{3}$ Receptor Mice}

Cocaine $(40 \mathrm{mg} / \mathrm{kg})$ produced PPI deficits in both D3R WT and $\mathrm{KO}$ mice (main effect of cocaine, $\mathrm{F}_{(1,36)}=53.8 ; P<0.01$ ) (Figure 2c). In addition, there was a genotype $\times$ cocaine interaction $\left(\mathrm{F}_{(1,36)}=6.1 ; P<0.01\right)$, indicative of a significant difference in the magnitude of the cocaine-elicited PPI deficit between the two genotypes. In contrast to the pattern observed with D2R mice, the PPI-disruptive effects of cocaine were exaggerated in D3R KO mice compared to WT animals. Cocaine had no effect on ASR in either gender, although there were significant main effects of sex $\left(\mathrm{F}_{(1,34)}=9.8 ; \quad P<0.01\right)$ and genotype $\left(\mathrm{F}_{(1,34)}=11.0\right.$; $P<0.01)$. Female mice exhibited lower ASR than their male counterparts and D3R KO mice had a lower ASR compared to WT mice (Table 1).

\section{DISCUSSION}

In support of our hypotheses, the results indicated that all three DA receptor subtypes contributed to the PPIdisrupting effects of cocaine in mice, although differentially. First, both the D1R antagonist SCH23390 and the D2/3R antagonist raclopride completely attenuated the PPI disruption produced by cocaine in $\mathrm{WT}$ mice. Second, mice lacking the D1R exhibited no cocaine-induced PPI deficits, suggesting that the D1R subtype is necessary for the PPI disruption caused by cocaine. Third, mice lacking the D2R displayed attenuated cocaine-induced PPI deficits, suggesting that activation of the D2R subtype contributes to the PPI disruption caused by cocaine. Fourth, mice lacking the D3R displayed exaggerated cocaine-induced PPI deficits, suggesting that activation of the D3 receptor subtype serves to inhibit the PPI disruption caused by cocaine. Each DA receptor subtype appears to be differentially modulating cocaine-induced PPI disruptions as seen by the lack of response in D1R KO mice, a weak response in D2R KO mice, and an exaggerated response in $\mathrm{D} 3 \mathrm{R}$ KO mice.

Mice lacking the DA D1R or those administered the D1R antagonist SCH23390 failed to show a cocaine-induced disruption in PPI. These observations corroborate and

Table I Acoustic Startle Response after Treatment with Vehicle or Cocaine $(40.0 \mathrm{mg} / \mathrm{kg})$

\begin{tabular}{|c|c|c|c|c|c|c|c|c|c|}
\hline \multirow[b]{2}{*}{ ASR } & \multicolumn{3}{|c|}{ WT } & \multicolumn{2}{|c|}{ DIR } & \multicolumn{2}{|c|}{ D2R } & \multicolumn{2}{|c|}{ D3R } \\
\hline & VEH & SCH & RAC & WT & KO & WT & KO & WT & KO \\
\hline VEH & $76.3 \pm 13.3$ & $66.4 \pm 15.4$ & $62.7 \pm 10.5$ & $59.2 \pm 10.6$ & $84.4 \pm 13.5$ & $1 \mid 1.3 \pm 11.3$ & $75.2 \pm 7.7$ & $81.9 \pm 9.0$ & $56.5 \pm 9.6$ \\
\hline $\mathrm{COC}$ & $55.7 \pm 10.4$ & $55.5 \pm 10.5$ & $67.7 \pm 15.5$ & $43.1 \pm 6.7$ & $83.8 \pm 12.5$ & $75.8 \pm 7.7$ & $66.8 \pm 7.2$ & $84.1 \pm 14.8$ & $43.4 \pm 6.2$ \\
\hline
\end{tabular}

Similar to PPI, acoustic startle response (ASR) has been collapsed across sex, given that the only interaction of sex with cocaine treatment occurred in male D2 WT

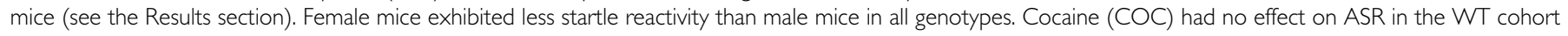
pretreated with vehicle (VEH), $1.0 \mathrm{mg} / \mathrm{kg} \mathrm{SCH} 23390(\mathrm{SCH})$, or $1.0 \mathrm{mg} / \mathrm{kg}$ raclopride (RAC). Cocaine had no effect on ASR in DIR and D3R mice. In D2R mice,

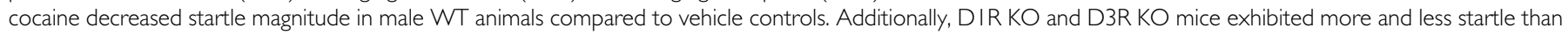

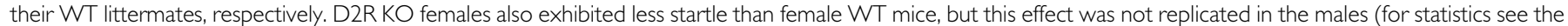
Results section). Data are presented as mean \pm SEM startle magnitudes in arbitrary units. 

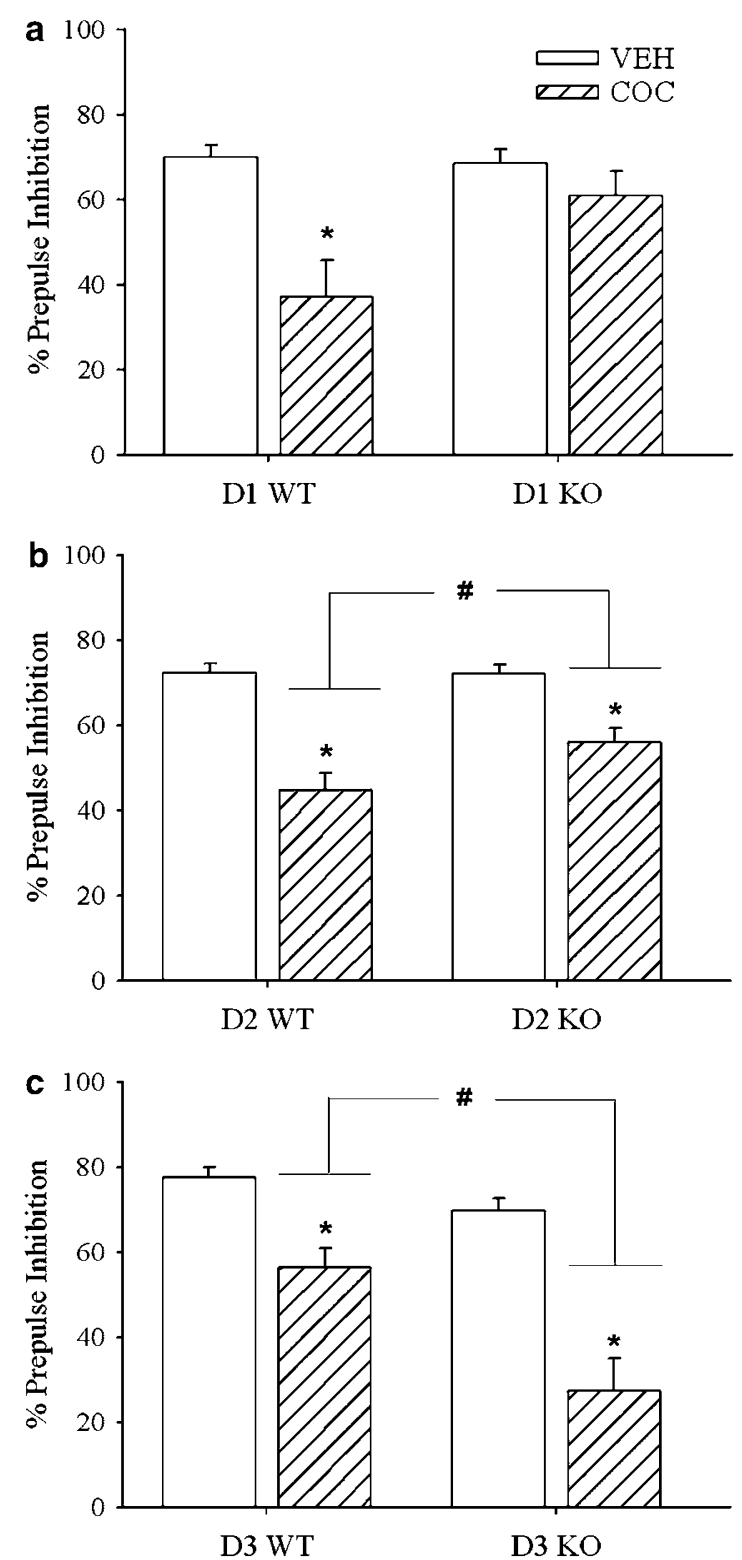

Figure 2 Prepulse inhibition of the startle response in DIR, D2R, and D3R mutant mice after vehicle (VEH) or $40.0 \mathrm{mg} / \mathrm{kg}$ cocaine (COC) treatment. (a) Cocaine decreased PPI in the DIR WT mice but not in the DIR KO mice. (b) Cocaine decreased PPI in both D2R WT and KO mice. In addition, D2R KO mice exhibited less disruption in PPI than D2R WT mice after cocaine treatment. (c) Cocaine decreased PPI in both D3R WT and $\mathrm{KO}$ mice. In addition, D3R KO mice exhibited a greater disruption in PPI than D3R WT mice after cocaine treatment. $* P<0.01$ compared to vehicle control. ${ }^{\#} P<0.025$ vs WT-COC. Data are presented as mean \pm SEM.

extend previous studies of mutant mice lacking the D1R, which demonstrated that D1Rs play a critical role in mediating the behavioral responses to cocaine. Both the acute, and to a lesser extent, chronic locomotor-stimulating effects of cocaine are reduced in D1R KO mice (Xu et al, 1994, 2000). D1R agonists and antagonists can influence locomotor and stereotyped responses to cocaine and alter cocaine self-administration patterns (Koob et al, 1987; Cabib et al, 1991; Caine and Koob, 1994; Tella, 1994; Self et al, 1996). Moreover, $\mathrm{D}_{1}$-like antagonists and partial agonists attenuated the reinforcing and discriminativestimulus effects of cocaine (Katz and Witkin, 1992; Spealman et al, 1997; Katz et al, 1999; Caine et al, 2000; David et al, 2004). Consistent with these observations in different behavioral paradigms, the present studies of PPI corroborate our previous evidence (Ralph-Williams et al, 2002, 2003) suggesting that activation of the $D 1 R$ is essential for the PPI-disruptive effects of either cocaine or mixed DA agonists.

In addition to the essential role of the D1R in the PPIdisruptive effect of cocaine, the present results support a model in which the activation by cocaine of both D2R and D3R also contribute in modulating PPI. Mice lacking the DA D2R exhibit attenuated cocaine-induced PPI deficits, while mice administered the $\mathrm{D} 2 / \mathrm{D} 3 \mathrm{R}$ antagonist raclopride fail to show a cocaine-induced disruption in PPI. The D2R has a direct protein-to-protein link to the presynaptic DA transporter (Lee et al, 2007), known to regulate dopaminergic tone, which could explain the attenuated cocaineinduced PPI deficits in D2R KO mice. These observations are consistent with the proposal by Xu (1998) that D3Rs modulate the response to psychostimulants by inhibiting the cooperative effects of postsynaptic $\mathrm{D}_{1^{-}}$and $\mathrm{D}_{2}$-family receptors (Daly and Waddington, 1992) at a systems level. In D2R KO mice, the weaker response to cocaine compared to WT animals may be attributed to the intact activation of D1R, which is partially attenuated by the opposing influence of the cocaine-induced activation of D3R. In contrast, the blockade of both D2R and D3Rs by raclopride clearly prevented the cocaine-induced activation of D1R from affecting PPI. Thus, it appears that co-activation of either $\mathrm{D} 2 \mathrm{R}$ or D3R is required for the activation of D1R by cocaine to disrupt PPI. When only one of these $\mathrm{D}_{2}$-family receptors was inactivated by gene deletions, the cocaine-induced activation of D1R was effective in disrupting PPI. The data from the current study suggest that activation of D1R by cocaine is necessary but not sufficient to disrupt PPI in mice.

Despite the present and previous evidence that some behavioral consequences of cocaine-induced activation of D1R require the concomitant activation of either the $D_{2}$ or $\mathrm{D}_{3}$ subtypes of the $\mathrm{D}_{2}$-family of DA receptors, the present findings further suggest that the permissive influences of $\mathrm{D} 2 \mathrm{R}$ and D3R in this context are opposite in direction. That is, in contrast to the D2R KO mice, mice lacking the DA D3R exhibited exaggerated cocaine-induced PPI deficits. One explanation could be that the elevated basal extracellular DA levels in D3 KO mice (Koeltzow et al, 1998; Joseph et al, 2002) could lead to the increased sensitivity to cocaine observed here in our D3 KO mice. There also seems to be opposing effects between the D1R and the D3R on the genomic effects of cocaine. The D1R activates and the D3R inhibits gene expression of extracellular kinases and c-fos induction after acute and chronic cocaine treatment (Zhang et al, 2004). Our results corroborate this hypothesis, as D1R KO mice display no cocaine-induced PPI deficits while D3R KO mice exhibit exaggerated cocaine-induced PPI deficits. These results corroborate and extend previous studies of psychostimulant effects in D3R KO mice. For example, D3R KO mice exhibit an enhanced locomotor response after cocaine administration (Carta et al, 2000) and D3R antagonists augment cocaine (Piercey et al, 1992) and 
amphetamine-stimulated locomotion (Waters et al, 1993; Pritchard et al, 2007). D3R KO mice also exhibit an increase in cocaine cue-conditioned hyperactivity and cocaine cueconditioned mice had increased levels of D3R mRNA in the nucleus accumbens compared to saline controls (Le Foll et al, 2002). It should be noted, however, that the effects of agonists and antagonists having preferential affinities for D3R over D2R are not entirely consistent with the effects observed with the more specific genetic manipulations of these receptor subtypes (eg Corbin et al, 1998; Le Foll et al, 2002; Xi et al, 2005). The development of more subtypeselective $\mathrm{D}_{2}$-family ligands or perhaps a double KO mouse in which both $\mathrm{D} 2 \mathrm{R}$ and $\mathrm{D} 3 \mathrm{R}$ are deleted would help to clarify the respective roles of these $\mathrm{DA}_{2}$-family receptor subtypes in modulating the effects of cocaine and other psychostimulants.

The contradictory literature on the behavioral effects of $\mathrm{D} 2 \mathrm{R} v s$ D3R agonists and antagonists may also be a reflection of regional differences in receptor subtype expression. Comparing between the two subtypes, the D2R exhibits higher expression in dorsal striatum, substantia nigra, and ventral tegmental area, whereas the D3R exhibits higher expression in nucleus accumbens (Callier et al, 2003). Also, differential pre- vs postsynaptic expression of the receptor subtypes in brain regions important for PPI may contribute to different effects on PPI.

Since both amphetamine and cocaine are indirect DA agonists that increase synaptic DA concentrations, it is puzzling that the D2R, not the D1R, is necessary for amphetamine to disrupt PPI (Ralph et al, 1999), while cocaine does not disrupt PPI in D1R KO mice. The DA transporter is an obligatory target of both cocaine and amphetamine, but there is conflicting evidence on psychostimulant effects on the DA transporter. In one study these psychostimulants have no effect on locomotor activity or DA release and uptake in DA transporter KO mice (Giros et al, 1996). In contrast, other studies have found that DA transporter KO mice display increased amphetamineinduced conditioned place preference, and cocaine- and amphetamine-stimulated increases in DA in the nucleus accumbens (Carboni et al, 2001; Budygin et al, 2004). Confounding these reports is Yamashita et al (2006), where cocaine actually increased PPI in DA transporter KO mice, presumably through norepinephrine (NE) transporter blockade. Also, Tilley et al (2007) found that DA transporter knockdown mice exhibit increased cocaine-stimulated locomotor activity. Nevertheless, there is evidence that amphetamine elevates extracellular DA by a transportermediated release of non-vesicular, and possibly vesicular DA, from dopaminergic terminals, whereas cocaine mainly acts by blocking DA uptake (Ary and Komiskey, 1982; Butcher et al, 1988; Hurd and Ungerstedt, 1989; Floor and Meng, 1996; Sabol and Seiden, 1998). Additionally, amphetamine induces immediate early gene $c$-fos expression mainly in striosomes, whereas cocaine causes an immediate $c$-fos expression in both the striosome and matrix compartments of the dorsal striatum in the rat (Graybiel et al, 1990). The striosomes and matrix are the major neurotransmitter-specific compartments in the dorsal striatum (Graybiel and Ragsdale, 1978; Graybiel et al, $1990)$ and have different limbic and sensorimotor affiliations with cortex and subcortex (Donoghue and Herken- ham, 1986; Ragsdale and Graybiel, 1990). Amphetamine and cocaine also lead to different $c$-fos expression patterns in the nucleus accumbens. Cocaine, but not amphetamine, elicited more expression of $c-f o s$ in the shell than in the core of nucleus accumbens (Graybiel et al, 1990). The nucleus accumbens is a key modulator of PPI (for review Swerdlow et al, 2001). The disruptive effects of amphetamine seem to correlate in time with DA increase in the nucleus accumbens in the rat (Zhang et al, 2000). Studies of mutant mice challenged with amphetamine and cocaine (Graybiel et al, 1990; Moratalla et al, 1996) indicate that the D1R is required to induce the expression of $c$-fos in striatal neurons. Combined with our behavioral results, these studies suggest that amphetamine and cocaine exert differential effects in rodents.

Although previous studies indicate that the D4R subtype does not influence PPI or the effect of amphetamine on PPI (Ralph et al, 1999), a contribution of the D4R subtype in cocaine-induced PPI deficits remains a possibility. The present results, showing the necessary role of the D1R in cocaine-induced PPI, and evidence from prior studies (Ralph et al, 1999; Holmes et al, 2001; Ralph-Williams et al, 2002, 2003; Ralph and Caine, 2005), indicate that the D5 DA receptor subtype has little contribution to psychostimulant-induced PPI deficits. Nevertheless, we cannot rule out a possible contribution of the D5R subtype to cocaineinduced PPI deficits.

Cocaine had slight but nonsignificant effects on startle reactivity in all experiments. Specifically, cocaine did not affect ASR in WT, D1R, D2R, or D3R mice, although D1R and D3R KO mice exhibited higher and lower startle than their WT counterparts, respectively. The only interaction of sex with cocaine treatment occurred in male D2R WT mice, where cocaine decreased ASR compared to vehicle controls. In general, some differences in ASR across experiments were due to male mice in all experiments exhibiting higher startle than female counterparts, regardless of genotype. Also, female D2R KO mice exhibited reduced startle compared to WT littermates, regardless of drug treatment. Although each of these lines has been backcrossed 7 (for $\mathrm{D} 1 \mathrm{R}$ and D3R mice) or 14 (for D2R mice) generations and are considered to be congenic to $\mathrm{C} 57 \mathrm{Bl} / 6 \mathrm{~J}$, there is the possibility of genetic drift in each line. These differences in startle magnitude between the lines of mice should not impact the interpretability of the effects of cocaine on PPI. First, each line was bred using heterozygous matings and studies were conducted in WT and KO littermates. All statistical comparisons were carried out within each line. Second, while the startle values did differ between the WT mice of each line, the percent PPI was very similar across the lines, demonstrating the independence of PPI and startle magnitude. Moreover, cocaine disrupted PPI in all three lines of WT mice. Our results in mice corroborate the study by Yamashita et al (2006) and extend it with behavioral data suggesting that amphetamine and cocaine exert differential effects in rodents.

Cocaine and amphetamine both increase available NE and serotonin $(5 \mathrm{HT})$, although in distinct manners that may be important for modulating PPI. Cocaine blocks, while amphetamine reverses, the norepinephrine transporter (NET) and serotonin transporter (SERT), and cocaine is more potent at SERT than amphetamine (Rothman and 
Baumann, 2003). In rats, the $\alpha-1 \mathrm{NE}$ antagonist prazosin and the $5 \mathrm{HT}_{2}$ antagonist ketanserin failed to reverse cocaine-induced PPI deficits (van der Elst et al, 2006), while the NE reuptake inhibitor desipramine, but not the 5HT reuptake inhibitor citalopram, normalized amphetamine-induced PPI disruptions (Pouzet et al, 2005). In mice, $\alpha 2 \mathrm{~A}-\mathrm{KO}$ mice were more sensitive to amphetamine-induced PPI disruption (Lahdesmaki et al, 2004) and NET is potentially involved in cocaine-induced PPI disruptions (Yamashita et al, 2006). Future studies should include a DA uptake inhibitor with little affinity for other neurotransmitter pathways to help elucidate the mechanistic differences between amphetamine and cocaine in terms of effects on PPI.

When using genetically engineered mice, the potential exists that some compensatory mechanisms may account for the differences observed in mutants since the mice lack the DA receptor throughout development. Developing inducible DA receptor $\mathrm{KO}$ mice, where the receptor loss can be turned on after critical developmental periods early in life, may eliminate developmental caveats. The DA receptor KO mice are used as model systems to gain a molecular understanding of acute effects of psychostimulants, such as cocaine and amphetamine. The mutant mice help define the role the different DA receptor subtypes play in the acute effects of psychostimulants, something unobtainable with the poor subtype-specific agonists and antagonists available today. Developing double KOs (eg D3R combined with either D1R or D2R), if viable, could also help explain the contributions of each DA receptor subtype since multiple receptors seem to be involved and subtypes may modulate each other. Genetically altered mice offer a unique model to test the specificity and selectivity of different DA drugs and may provide important new concepts related to the clinical and social implications of conditions displaying dysregulated DA systems, such as Parkinson's disease, drug addiction, and schizophrenia.

The results of the present study support differential roles for the DA D1R, D2R, and D3R subtypes in modulating cocaine-induced disruption of PPI in mice. Further evidence is needed to explain fully the differences in rodent responses to psychostimulant drugs depending upon whether their DA receptors are manipulated pharmacologically or genetically. Deciphering the role that specific DA receptors play in modulating behavioral effects will help explain disorders involving DA, such as schizophrenia and drug abuse.

\section{ACKNOWLEDGEMENTS}

We thank Mahálah Buell, Sorana Caldwell, and Renee Bend for their technical assistance and Dr Victoria Risbrough for helpful comments on the manuscript.

\section{DISCLOSURE/CONFLICT OF INTEREST}

These studies were supported by NIH MH61326, DA02925 and the Veterans Affairs VISN 22 Mental Illness Research, Education, and Clinical Center. We declare that over the past 3 years MAG has received compensation from Abbott, Acadia, Addex, Amgen, AstraZeneca, Bristol-Myers Squibb,
Jazz, Organon, Nura, San Diego Instruments, Serono, and Wyeth-Ayerst and holds an equity interest in San Diego Instruments and MJL has received royalty income and/or stock shares from Amgen, Caliper Life Sciences, Lilly, Orexigen, Pfizer, and Thiakis in compensation for the licensing of intellectual property assigned to OHSU, including the D2R KO mice used in this study.

\section{REFERENCES}

Accili D, Fishburn CS, Drago J, Steiner H, Lachowicz JE, Park BH et al (1996). A targeted mutation of the D3 dopamine receptor gene is associated with hyperactivity in mice. Proc Natl Acad Sci USA 93: 1945-1949.

Ary TE, Komiskey HL (1982). Phencyclidine-induced release of $[3 \mathrm{H}]$ dopamine from the chopped striatal tissue. Neuropharmacology 21: 639-645.

Bolla KI, Cadet JL, London ED (1998). The neuropsychiatry of chronic cocaine abuse. J Neuropsychiatry Clin Neurosci 10: 280-289.

Braff DL, Geyer MA, Swerdlow NR (2001). Human studies of prepulse inhibition of startle: normal subjects, patient groups, and pharmacological studies. Psychopharmacology (Berl) 156: 234-258.

Budygin EA, Brodie MS, Sotnikova TD, Mateo Y, John CE, Cyr M et al (2004). Dissociation of rewarding and dopamine transportermediated properties of amphetamine. Proc Natl Acad Sci USA 101: 7781-7786.

Butcher SP, Fairbrother IS, Kelly JS, Arbuthnott GW (1988). Amphetamine-induced dopamine release in the rat striatum: an in vivo microdialysis study. J Neurochem 50: 346-355.

Byrnes JJ, Hammer RP (2000). The disruptive effect of cocaine on prepulse inhibition is prevented by repeated administration in rats. Neuropsychopharmacology 22: 551-554.

Cabib S, Castellano C, Cestari V, Filibeck V, Puglisi-Allegra S (1991). D1 and D2 receptor antagonists differently affect cocaine-induced locomotor hyperactivity in the mouse. Psychopharmacology (Berl) 105: 335-339.

Caine SB, Koob GF (1994). Effects of dopamine D-1 and D-2 antagonists on cocaine-self-administration under different schedules of reinforcement in the rat. J Pharmacol Exp Ther 270: $209-218$.

Caine SB, Negus SS, Mello NK, Bergman J (2000). Effects of dopamine D1-like and D2-like agonists in rats trained to discriminate cocaine from saline: influence of experimental history. Exp Clin Psychopharmacol 8: 404-414.

Callier S, Snapyan M, Le Crom S, Prou D, Vincent JD, Vernier P (2003). Evolution and cell biology of dopamine receptors in vertebrates. Biol Cell 95: 489-502.

Carboni E, Spielewoy C, Vacca C, Nosten-Bertrand M, Giros B, Di Chiara G (2001). Cocaine and amphetamine increase extracellular dopamine in the nucleus accumbens of mice lacking the dopamine transporter gene. J Neurosci 21: 1-4.

Carta AR, Gerfen CR, Steiner H (2000). Cocaine effects on gene regulation in the striatum and behavior: increased sensitivity in D3 dopamine receptor-deficient mice. NeuroReport 11: 2395-2399.

Chausmer AL, Elmer GL, Runbinstein M, Low MJ, Grandy DK, Katz JL (2002). Cocaine-induced locomotor activity and cocaine distribution in dopamine D2 receptor mutant mice. Psychopharmacology (Berl) 163: 54-61.

Corbin AE, Pugsley TA, Akunne HC, Whetzel SZ, Zoski KT, Georgic LM et al (1998). Pharmacological characterization of PD 152255, a novel dimeric benzimidazole dopamine D3 antagonist. Pharmacol Biochem Behav 59: 487-493.

Daly SA, Waddington JL (1992). Two directions of dopamine $\mathrm{D} 1 / \mathrm{D} 2$ receptor interaction in studies of behavioural regulation: 
a finding generic to four new, selective dopamine D1 receptor antagonists. Eur J Pharmacol 213: 251-258.

David V, Segu L, Buhot MC, Ichaye M, Cazala P (2004). Rewarding effects elicited by cocaine microinjections into the ventral tegmental area of C57BL/6 mice: involvement of dopamine D1 and serotonin1B receptors. Psychopharmacology (Berl) 174: 367-375.

Díaz-Torga G, Feierstein C, Libertun C, Gelman D, Kelly MA, Low MJ et al (2002). Disruption of the D2 dopamine receptor alters GH and IGF-I secretion and causes dwarfism in male mice. Endocrinology 143: 1270-1279.

Donoghue JP, Herkenham M (1986). Neostriatal projections from individual cortical fields conform to histochemically distinct striatal compartments in the rat. Brain Res 365: 397-403.

Drago J, Gerfen CR, Lachowicz JE, Steiner H, Hollon TR, Love PE et al (1994). Altered striatal function in a mutant mouse lacking D1A dopamine receptors. Proc Natl Acad Sci USA 91: 12564-12568.

Floor E, Meng L (1996). Amphetamine releases dopamine from synaptic vesicles by dual mechanisms. Neurosci Lett 215: 53-56.

Geyer MA, Dulawa SC (2003). Assessment of murine startle reactivity, prepulse inhibition, and habituation, In: Crawley JN and Skolnick P (eds). Current Protocols in Neuroscience. John Wiley \& Sons: New York. pp 8.17.1-8.17.15.

Geyer MA, Krebs-Thomson K, Braff DL, Swerdlow NR (2001). Pharmacological studies of prepulse inhibition models of sensorimotor gating deficits in schizophrenia: a decade in review. Psychopharmacology (Berl) 156: 117-154.

Geyer MA, McIlwain KL, Paylor R (2002). Mouse genetic models for prepulse inhibition: an early review. Mol Psychiatry 7: 1039-1053.

Giros B, Jaber M, Jones SR, Wightman RM, Caron MG (1996). Hyperlocomotion and indifference to cocaine and amphetamine in mice lacking the dopamine transporter. Nature 379: 606-612.

Graybiel AM, Moratalla R, Robertson HA (1990). Amphetamine and cocaine induce drug specific activation of the c-fos gene in striosome-matrix compartments and limbic subdivisions of the striatum. Proc Natl Acad Sci USA 87: 6912-6916.

Graybiel AM, Ragsdale CW (1978). Histochemically distinct compartments in the striatum of human, monkeys, and cat demonstrated by acetylthiocholinesterase staining. Proc Natl Acad Sci USA 75: 5723-5726.

Hoffman HS, Ison JR (1980). Reflex modification in the domain of startle: I. Some empirical findings and their implications for how the nervous system processes sensory input. Psychol Rev 87: 175-189.

Holmes A, Hollon TR, Gleason TC, Liu Z, Dreiling J, Sibley DR et al (2001). Behavioral characterization of dopamine D5 receptor null mutant mice. Behav Neurosci 115: 1129-1144.

Hurd YL, Ungerstedt U (1989). Cocaine: an in vivo microdialysis evaluation of its acute action on dopamine transmission in rat striatum. Synapse 3: 48-54.

Joseph JD, Wang YM, Miles PR, Budygin EA, Picetti R, Gainetdinov RR et al (2002). Dopamine autoreceptor regulation of release and uptake in mouse brain slices in the absence of D3 receptors. Neuroscience 112: 39-49.

Katz JL, Kopajtic TA, Myers K, Mitkus R, Chider M (1999). The behavioral effects of cocaine: interactions with $\mathrm{D} 1$ dopaminergic antagonists and partial agonists in mice and squirrel monkeys. J Pharmacol Exp Ther 291: 265-279.

Katz JL, Witkin JM (1992). Effects of quinpirole and SKF 38393 alone and in combination in squirrel monkeys trained to discriminate cocaine. Psychopharmacology (Berl) 107: 217-220.

Kelly MA, Rubinstein M, Asa SL, Zhang G, Saez C, Bunzow JR et al (1997). Pituitary lactotroph hyperplasia and chronic hyperprolactinemia in dopamine D2 receptor-deficient mice. Neuron 19: $103-113$.

Kelly MA, Rubinstein M, Phillips TJ, Lessov CN, Burkhart-Kasch S, Zhang G et al (1998). Locomotor activity in D2 dopamine receptor-deficient mice is determined by gene dosage, genetic background, and developmental adaptations. J Neurosci 18: 3470-3479.

Koeltzow TE, Xu M, Cooper DC, Hu XT, Tonegawa S, Wolf ME et al (1998). Alterations in dopamine release but not dopamine autoreceptor function in dopamine D3 receptor mutant mice. J Neurosci 18: 2231-2238.

Koob GF, Le HT, Creese I (1987). The D1 dopamine receptor antagonist SCH23390 increases cocaine self-administration in the rat. Neurosci Lett 79: 315-320.

Lahdesmaki J, Sallinen J, MacDonald E, Scheinin M (2004). Alpha2A-adrenoceptors are important modulators of the effects of D-amphetamine on startle reactivity and brain monoamines. Neuropsychopharmacology 29: 1282-1293.

Le Foll B, Frances H, Diaz J, Schwartz JC, Sokoloff P (2002). Role of the dopamine D3 receptor in reactivity to cocaine-associated cues in mice. Eur J Neurosci 15: 2016-2026.

Lee FJ, Pei L, Moszczynska A, Vukusic B, Fletcher PJ, Liu F (2007). Dopamine transporter cell surface localization facilitated by a direct interaction with the dopamine D2 receptor. EMBO J 26: 2127-2136.

Martinez ZA, Ellison GD, Geyer MA, Swerdlow NR (1999). Effects of sustained cocaine exposure on sensorimotor gating of startle in rats. Psychopharmacology (Berl) 142: 253-260.

Moratalla R, Vallejo M, Elibol B, Graybiel AM (1996). D1-class dopamine receptors influence cocaine-induced persistent expression of Fos-related proteins in striatum. NeuroReport 8: 1-5.

Piercey MF, Lum JT, Hoffmann WE, Carlsson A, Ljung E, Svensson K (1992). Antagonism of cocaine's pharmacological effects by the stimulant dopaminergic antagonists, (+)-AJ76 and (+)-UH232. Brain Res 588: 217-222.

Pouzet B, Andersen MP, Hogg S (2005). Effects of acute treatment with antidepressant drugs on sensorimotor gating deficits in rats. Psychopharmacology (Berl) 178: 9-16.

Pritchard LM, Newman AH, McNamara RK, Logue AD, Taylor B, Welge JA et al (2007). The dopamine D3 receptor antagonist NGB 2904 increases spontaneous and amphetamine-stimulated locomotion. Pharmacol Biochem Behav 86: 718-726.

Ragsdale Jr CW, Graybiel AM (1990). A simple ordering of neocortical areas established by the compartmental organization of their striatal projections. Proc Natl Acad Sci USA 87: 6196-6199.

Ralph RJ, Caine SB (2005). Dopamine D1 and D2 agonist effects on prepulse inhibition and locomotion: comparison of SpragueDawley rats to Swiss-Webster, 129X1/SvJ, C57BL/6J, and DBA/2J mice. J Pharmacol Exp Ther 312: 733-741.

Ralph RJ, Caine SB (2007). Effects of selective dopamine D1-like and D2-like agonists on prepulse inhibition of startle in inbred C3H/HeJ, SPRET/EiJ, and CAST/EiJ mice. Psychopharmacology (Berl) 191: 731-739.

Ralph RJ, Varty GB, Kelly MA, Wang YM, Caron MG, Rubinstein M et al (1999). The dopamine D2, but not D3 or D4, receptor subtype is essential for the disruption of prepulse inhibition produced by amphetamine in mice. J Neurosci 19: 4627-4633.

Ralph-Williams RJ, Lehmann-Masten V, Geyer MA (2003). Dopamine D1 rather than D2 receptor agonists disrupt prepulse inhibition of startle in mice. Neuropsychopharmacology 28: 108-118.

Ralph-Williams RJ, Lehmann-Masten V, Otero-Corchon V, Low MJ, Geyer MA (2002). Differential effects of direct and indirect dopamine agonists on prepulse inhibition: a study in D1 and D2 receptor knock-out mice. J Neurosci 22: 9604-9611.

Rothman RB, Baumann MH (2003). Monoamine transporters and psychostimulant drugs. Eur J Pharmacol 479: 23-40.

Rouge-Pont F, Usiello A, Benoit-Marand M, Gonon F, Piazza PV, Borrelli E (2002). Changes in extracellular dopamine induced by morphine and cocaine: crucial control by D2 receptors. J Neurosci 22: 3293-3301. 
Sabol KE, Seiden LS (1998). Reserpine attenuates d-amphetamine and MDMA-induced transmitter release in vivo: a consideration of dose, core temperature and dopamine syntheses. Brain Res 806: 69-78.

Self DW, Barnhart WJ, Lehman DA, Nestler EJ (1996). Opposite modulation of cocaine-seeking behavior by D1- and D2-like dopamine receptor agonists. Science 271: 1586-1589.

Spealman RD, Bergman J, Rosenzweig-Lipson S (1997). Differential modulation of behavioral effects of cocaine by low- and highefficacy D1 agonists. Psychopharmacology (Berl) 133: 283-292.

Swerdlow NR, Geyer MA, Braff DL (2001). Neural circuit regulation of prepulse inhibition of startle in the rat: current knowledge and future challenges. Psychopharmacology (Berl) 156: $194-215$.

Tella SR (1994). Differential blockade of chronic versus acute effects of intravenous cocaine by dopamine receptor antagonists. Pharmacol Biochem Behav 48: 151-159.

Tilley MR, Cagniard B, Zhuang X, Han DD, Tiao N, Gu HH (2007). Cocaine reward and locomotion stimulation in mice with reduced dopamine transporter expression. BMC Neurosci 8: 1-7.

Van der Elst MC, Ellenbroek BA, Cools AR (2006). Cocaine strongly reduces prepulse inhibition in apomorphine-susceptible rats, but not in apomorphine-unsusceptible rats: regulation by D2 receptors. Behav Brain Res 175: 392-398.

Varty GB, Higgins GA (1998). Dopamine agonist-induced hypothermia and disruption of prepulse inhibition: evidence for a role of D3 receptors? Behav Pharmacol 9: 445-455.

Waters N, Svensson K, Haadsma-Svensson SR, Smith MW, Carlsson A (1993). The dopamine D3-receptor: a postsynaptic

receptor inhibitory on rat locomotor activity. J Neural Transm Gen Sect 94: 11-19.

Xi ZX, Gilbert JG, Pak AC, Ashby Jr CR, Heidbreder CA, Gardner EL (2005). Selective dopamine D3 receptor antagonism by SB-277011A attenuates cocaine reinforcement as assessed by progressive-ratio and variable-cost-variable-payoff fixedratio cocaine self-administration in rats. Eur $J$ Neurosci 21: 3427-3438.

Xu M (1998). Unraveling dopamine D3 receptor function in response to psychostimulants using a genetic approach. Ann N Y Acad Sci 844: 27-39.

Xu M, Guo Y, Vorhees CV, Zhang J (2000). Behavioral responses to cocaine and amphetamine administration in mice lacking the dopamine D1 receptor. Brain Res 852: 198-207.

Xu M, Hu XT, Cooper DC, Moratalla R, Graybiel AM, White FJ et al (1994). Elimination of cocaine-induced hyperactivity and dopamine-mediated neurophysiological effects in dopamine D1 receptor mutant mice. Cell 79: 945-955.

Yamashita M, Fukushima S, Shen H, Hall FS, Uhl GR, Numachi Y et al (2006). Norepinephrine transporter blockade can normalize the prepulse inhibition deficits found in dopamine transporter knockout mice. Neuropsychopharmacology 31: 2132-2139.

Zhang J, Forkstam C, Engel JA, Svensson L (2000). Role of dopamine in prepulse inhibition of acoustic startle. Psychopharmacology (Berl) 149: 181-188.

Zhang L, Lou D, Jiao H, Zhang D, Wang X, Xia Y et al (2004). Cocaine-induced intracellular signaling and gene expression are oppositely regulated by the dopamine D1 and D3 receptors. J Neurosci 24: 3344-3354. 